\title{
The Influence of Electrochemical Pre-Treatment of B-Doped Diamond Films on the Electrodeposition of Pt
}

\author{
Mauro C. Ribeiro, Leide G. da Silva ${ }^{\#}$ and Paulo T. A. Sumodjo* \\ Instituto de Química, Universidade de São Paulo, Av. Prof. Lineu Prestes, 748, 05508-900 São Paulo-SP Brazil
}

\begin{abstract}
Este trabalho trata da influência do pré-tratamento eletroquímico de eletrodos de diamante dopado com boro (DDB) em meio ácido, na eletrodeposição de platina. Pt não pôde ser eletrodepositada em eletrodos de DDB recém-preparados. Entretanto, pré-tratamentos baseados em varreduras de potenciais ou em polarizações anódicas a potencial constante em curtos intervalos de tempo ativaram o eletrodo para a deposição de Pt. O tratamento anódico desempenha diferentes papéis, de acordo com o tempo de tratamento: em tempos curtos, a deposição de $\mathrm{Pt}$ é aumentada, ao passo que tempos de polarização mais longos inibem o processo de eletrodeposição de Pt, originando, entretanto, depósitos com maior área superficial. Tais resultados são discutidos em termos de mudanças na hidrofilicidade da superfície do DDB, bem como na apassivação da superfície, provavelmente representada pela oxidação da mesma.
\end{abstract}

The influence of the substrate electrochemical pre-treatment in $0.5 \mathrm{~mol} \mathrm{~L}^{-1} \mathrm{H}_{2} \mathrm{SO}_{4}$ on the $\mathrm{Pt}$ electrodeposition on boron-doped diamond, BDD, film electrodes was investigated. Platinum cannot be electrodeposited on a freshly prepared BDD electrode; however, potentiodynamic cycling or anodic potential steps at short times does activate the electrode. Anodic pre-treatment plays a dual role in the behavior of Pt deposition on BDD surfaces: Pt deposition is increased at short-term anodic pre-treatments, whereas at longer pre-treatment times Pt deposition was inhibited. These facts are explained in terms of wettability changes and passivation of the surface. Conversely, the oxide layer formed in these treatments increases the dispersion level of the catalyst.

Keywords: boron-doped diamond electrodes, Pt electrodeposition, electro oxidation

\section{Introduction}

As Solar Energy technology is not yet fully developed to be commercially employed, fuel cells constitute one of the best alternative for energy conversion devices as a substituent to the pollutant fossil fuel powered engines. ${ }^{1}$ Several electrode materials have been proposed for fuel cells. In these devices, the electrode is basically constituted of Pt clusters anchored on finely divided carbon black substrate. For this reason, the dispersion of electrocatalysts on carbonous materials has been intensely investigated. Among several parameters, the nature and pre-treatment of the substrate arise as interesting ways to control important characteristics like the size, stability and activity of the electrocatalyst particles. Several authors have

*e-mail: ptasumod@iq.usp.br

"Present Address: Instituto Nacional de Pesquisas Espaciais - INPE, CP 515, 12201-970 São José dos Campos - SP, Brazil studied the influence of the nature of the substrate on the electrocatalytic activity of platinum dispersions and it was observed for example, that the work function of the substrate can strongly influence the activity of the electrocatalyst. ${ }^{2}$ It was shown that the electrocatalytic activity of $\mathrm{Ag}$ dispersions for $\mathrm{O}_{2}$ cathodic reduction increased as the carbonous substrate oxidation level increased. ${ }^{3}$ Thus, oxidative pretreatment of the carbonous substrate can influence the dispersion and activity of the catalyst. Conversely, different authors have noted that dispersion level of Pt nanoparticles is dependent of the presence of oxides on the carbonous substrate and with the electronic nature of the catalyst. ${ }^{4,5}$

It is a fact that at long term use carbonous materials suffer corrosion and microstructural degradation. ${ }^{6}$ Borondoped, conductive, polycristalline CVD diamond film, BDD, is known by its good conductivity, corrosion resistance, wide potential window and possibility of surfacial modification with metals and oxides. For this reason, such material has 
been regarded as a superior material in electroanalysis ${ }^{7}$, electrosynthesis, ${ }^{8}$ electrochemical effluent remediation ${ }^{9}$ and in fuel cells as electrode material. ${ }^{10}$ In the specific case of $\mathrm{Pt}$ surfacial modified BDD films, interesting results were already obtained. Honda et al. ${ }^{11}$ have studied Pt deposition on nanostructured BDD surfaces with larger electrochemical area for methanol anodic oxidation. Wang and Swain ${ }^{10}$ by both sputtering and electrodeposition, have achieved the deposition of stable anchored Pt nanoparticles on BDD films, which endured 2000 cicles between the HER and OER potentials in acidic media, or even after vigorous electrolysis in high temperatures and high current densities. Furthermore, they observed that the electrodeposited Pt particle size and dispersion were more effectively adjusted via electrochemical deposition of Pt than by the chemical route. Recently, Montilla et al. ${ }^{12}$ have deposited Pt on BDD for methanol oxidation, although they did not obtained satisfactorily stable Pt dispersions, possibly due to the weak interaction between the Pt nanoparticles and the BDD surface.

In the studies of the BDD surface pre-treatment for metal electrodeposition, it was interestingly shown that more uniform $\mathrm{Cu}$ deposition was obtained only when the electrode is pre-treated by $\mathrm{H}_{2}$ fotoelectrogeneration and that the electrode seemed to keep this behavior even after chemical stripping of the metal. ${ }^{13}$ On the other hand, it was observed that $\mathrm{Cu}$ was inhibited when the electrode surface was oxidized. ${ }^{14}$ The authors explained the observations in terms of either the formation of a surface oxide layer which exerts ion repulsion, or the blocking of active sites for metal deposition. Therefore, the question around the influence of surface chemistry of BDD films on the electrochemical processes ocurring at these electrodes is still controversial and thus needs to be more investigated. For these reasons this paper discusses the effect of the electrochemical pretreatment on the electrodeposition of Pt on BDD films for electrocatalytical purposes.

\section{Experimental}

BDD films were grown by the MWCVD process, on n$\mathrm{Si}$ waffer substrates, from a $0.5 \% \mathrm{CH}_{4}$ solution in $\mathrm{H}_{2}$. The doping level was estimated from the $\mathrm{B}_{2} \mathrm{O}_{5}$ concentration in the methanol stream injected into the CVD reaction chamber. Nominal doping level was 10000 ppm. The samples were characterized by Raman spectroscopy, which showed a single peak in $1332 \mathrm{~cm}^{-1}$, demonstrating the good quality of the samples.

Electrochemical measurements were performed using an EG\&G, PAR model $273 \mathrm{~A}$ and the electrochemical cell was a conventional three electrode one. A big area platinized Pt electrode was the counter electrode and the reference was a $\mathrm{Ag} \mid \mathrm{AgCl}$ electrode. All the potentials are referred to this electrode. The BDD film samples were adapted in brass rods sealed by a Teflon cap to avoid corrosion of the metallic suport. The geometric area of the BDD film exposed to the electrolyte was $0.2 \mathrm{~cm}^{2}$; currents and charges were normalized in terms of the geometric area. Electrochemical pre-treatment of the electrode consisted of potential holds at a potential in the $\mathrm{H}_{2}$ or $\mathrm{O}_{2}$ evolution potential region for a fixed period of time in $0.5 \mathrm{~mol} \mathrm{~L}^{-1} \mathrm{H}_{2} \mathrm{SO}_{4}$. The composition of the $\mathrm{Pt}$ plating bath was: $3.8 \times 10^{-3} \mathrm{~mol} \mathrm{~L}^{-1} \mathrm{H}_{2} \mathrm{PtCl}_{6}+0.1 \mathrm{~mol} \mathrm{~L}^{-1}$ $\mathrm{KCl}, \mathrm{pH}$ 3.4. The solutions were deoxygenated by nitrogen bubbling and the experiments were run at room temperature. Other solutions were eventually used and those ones, as well as specific experimental details, when necessary, are described in the Results and Discussion section. For the surface examination and EDS analysis, a JEOL (JSM 5310) scanning electron microscope was used.

\section{Results and Discussion}

\section{Effect of the deposition potential}

Linear potential sweep experiments were performed to determine the potential region related to Pt electrodeposition. Figure 1, curve (a) shows the voltammogram of a BDD electrode submitted to a linear potential scan from $0.75 \mathrm{~V}$ to $-2.0 \mathrm{~V}$ at a potential sweep rate of $50 \mathrm{mV}$ $\mathrm{s}^{-1}$ in $0.1 \mathrm{~mol} \mathrm{~L}^{-1} \mathrm{KCl}$ ( $\mathrm{pH} 3.4$ ). It shows the usual capacitive region and the hydrogen evolution reaction, HER, occurring at potentials more negative than $-1.6 \mathrm{~V}$. When an as-grown prepared BDD electrode was submitted to the same perturbation program in the Pt plating bath, no apparent difference from Figure 1 (a) was observed (not shown). This shows the inertness of the electrode for $\mathrm{Pt}$ deposition. Another BDD electrode was submitted to two consecutive triangular potential scans in $0.5 \mathrm{~mol} \mathrm{~L}^{-1} \mathrm{H}_{2} \mathrm{SO}_{4}$ at $50 \mathrm{mV} \mathrm{s}^{-1}$ between 0 and $1.6 \mathrm{~V}$. Then this electrode was submitted to a linear potential scan from $0.75 \mathrm{~V}$ to $-2.0 \mathrm{~V}$ at a potential sweep rate of $50 \mathrm{mV} \mathrm{s}^{-1}$ in $0.1 \mathrm{~mol} \mathrm{~L}^{-1} \mathrm{KCl}+$ $3.8 \times 10^{-3} \mathrm{~mol} \mathrm{~L}^{-1} \mathrm{H}_{2} \mathrm{PtCl}_{6}(\mathrm{pH} 3.4)$. The resulting voltammogram was the one depicted in Figure 1 (b). It shows a broad cathodic current peak at $c a$. $-0.53 \mathrm{~V}$, followed by the HER at potentials lower than $-0.95 \mathrm{~V}$. Inspection of Figure 1, (a) and (b) allows to infer that the observed current peak at $-0.53 \mathrm{~V}$ in the presence of $\mathrm{Pt}(\mathrm{IV})$ is related to Pt electrodeposition. Figure 1 (c) shows the voltammogram of the Pt deposited BDD electrode, $\mathrm{BDD}(\mathrm{Pt})$, in the supporting electrolyte $\left(0.1 \mathrm{~mol} \mathrm{~L}^{-1} \mathrm{KCl}\right)$. On the $\operatorname{BDD}(\mathrm{Pt})$ electrode the onset of the HER occurs at potentials much less negative (approximately $-0.8 \mathrm{~V}$ ) than 
on a BDD (around $-1.6 \mathrm{~V}$ ). This is obvious because of the lower hydrogen overpotential on Pt. A blow-up of Figure 1 (c) in the potential region between $+0.8 \mathrm{~V}$ and $-0.8 \mathrm{~V}$ is shown in the inset. It reveals the two cathodic current peaks related to hydrogen adsorption on platinum, confirming the presence of Pt on the BDD surface. The role of electrochemical pre-treatment of BDD electrodes for Pt electrodeposition is discussed in the next sections.

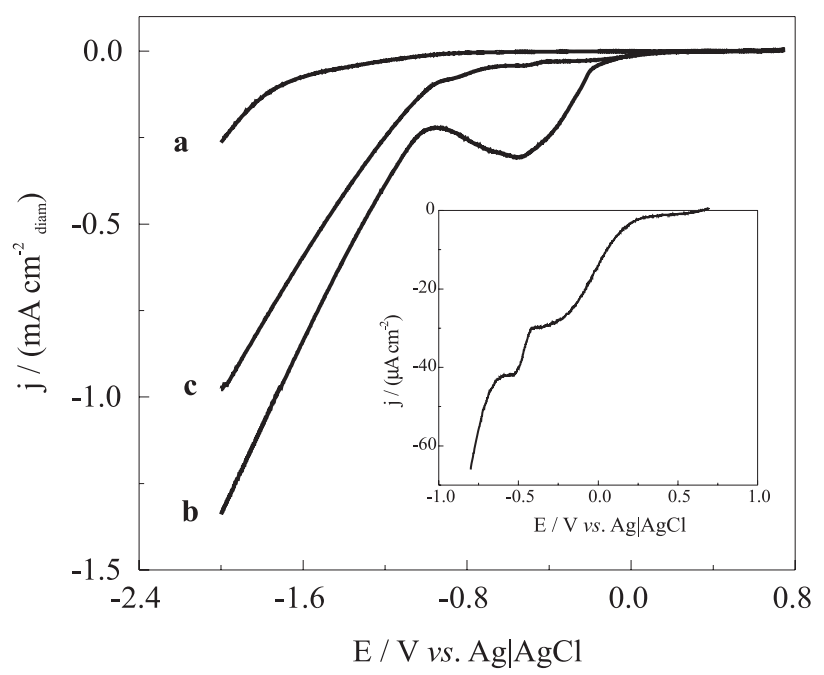

Figure 1. Linear potential sweep voltammograms for (a) BDD $\mid 0.1 \mathrm{~mol} \mathrm{~L}^{-1}$ $\mathrm{KCl}$, pH 3.4; (b) $\mathrm{BDD} \mid 3.8 \times 10^{-3} \mathrm{~mol} \mathrm{~L}^{-1} \mathrm{H}_{2} \mathrm{PtCl}_{6}+0.1 \mathrm{~mol} \mathrm{~L}^{-1} \mathrm{KCl}$, pH 3.4 and (c) $\mathrm{BDD}(\mathrm{Pt}) \mid 0.1 \mathrm{~mol} \mathrm{~L}^{-1} \mathrm{KCl}, \mathrm{pH} 3.4$ electrodes. $\mathrm{v}=50 \mathrm{mV} \mathrm{s}^{-1}$. Room temperature. The insert shows a blow-up of voltammogram $1 \mathrm{c}$ in the potential region between $+0.8 \mathrm{~V}$ and $-0.8 \mathrm{~V}$.

From the results shown in Figure 1 (b), Pt was deposited at constant potential at two different potentials: $-0.2 \mathrm{~V}$ and $-0.9 \mathrm{~V}$, the onset and the apparent end of the deposition current peak, respectively. The electric charge passed through the cell was $992 \mathrm{mC}$ $\mathrm{cm}^{-2}$ and $788 \mathrm{mC} \mathrm{cm}^{-2}$ at $-0.2 \mathrm{~V}$ and $-0.9 \mathrm{~V}$, respectively. After Pt deposition, the electrodes were submitted to a repetitive triangular potential scan at $50 \mathrm{mV} \mathrm{s}^{-1}$ in 0.5 mol L-1 $\mathrm{H}_{2} \mathrm{SO}_{4}$ in the potential range from $0.1 \mathrm{~V}$ to $1.5 \mathrm{~V}$ until attainment of a stable E/I profile. Figure 2 shows the typical cyclic voltammograms of the BDD and $\mathrm{BDD}(\mathrm{Pt})$ electrodes obtained in $0.5 \mathrm{~mol} \mathrm{~L}^{-1} \mathrm{H}_{2} \mathrm{SO}_{4}$. The bare BDD electrode shows its known inertness (Figure 2 (a)) whilst the Pt containing BDD electrode shows the usual voltammetric characteristics of $\mathrm{Pt}$ in that medium (Figure 2 (b)).

To check the efficiency of the BDD surface modification by $\mathrm{Pt}$ deposition, for electrocatalytic processes, a triangular potential scan was applied to the two $\mathrm{BDD}(\mathrm{Pt})$ electrodes in $0.5 \mathrm{~mol} \mathrm{~L}^{-1} \mathrm{H}_{2} \mathrm{SO}_{4}+0.1 \mathrm{~mol}$ $\mathrm{L}^{-1} \mathrm{C}_{2} \mathrm{H}_{5} \mathrm{OH}$. Ethanol was chosen because it is well known that the mechanism of ethanol electro-oxidation involves chemisorbed species and it is also well known that BDD

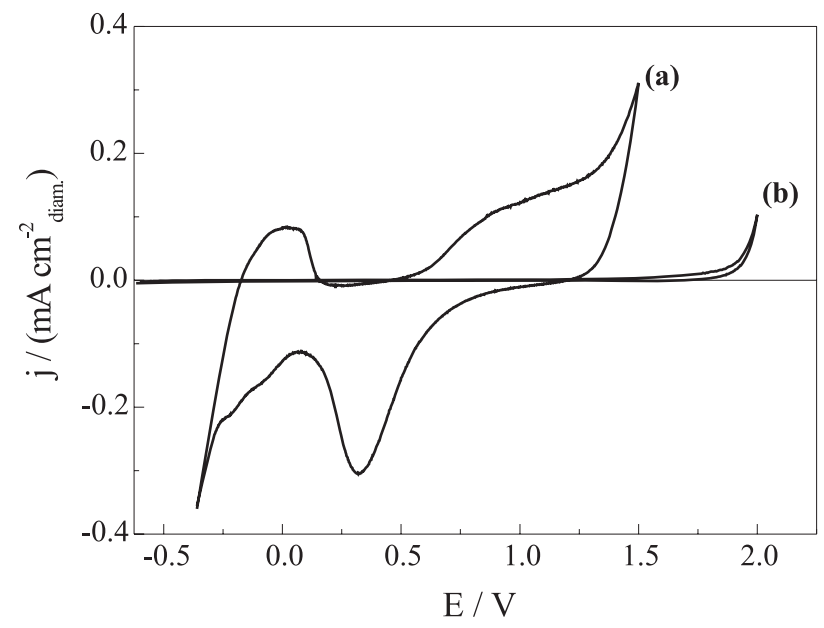

Figure 2. Potentiodynamic E/I profiles for (a) BDD and (b) BDD(Pt) electrodes in $0.5 \mathrm{~mol} \mathrm{~L}^{-1} \mathrm{H}_{2} \mathrm{SO}_{4}$ at $\mathrm{v}=50 \mathrm{mV} \mathrm{s}^{-1}$.

electrodes are unsuited for such processes because of the nature of diamond itself. Figure 3 depicts the resulting cyclic voltammograms. The general feature of the cyclic voltammograms is already well established in the literature and is associated with the oxidation and reduction reactions on a platinum electrode..$^{15,16}$ Accordingly, during the positive going potential excursion the anodic current peak that appeared at $c a$. $0.8 \mathrm{~V}$ is related to the adsorption and oxidation of ethanol on a Pt surface. At more positive potentials ethanol continued to be oxidized and also occurred Pt oxidation. The anodic peak current at $c a .1 .3 \mathrm{~V}$ is related to ethanol oxidation on a platinum oxide surface. When the direction of the potential scan was reversed, the observed cathodic current peak is related to the reduction of platinum oxide anodically formed. Immediately after the oxide reduction, the anodic current that appeared is due to oxidation of ethanol on a freshly activated Pt surface. The same experiment run on a BDD electrode (not shown) resulted in a voltammogram showing only a negligible capacitive current, indicating the inertness of the BDD surface for ethanol oxidation, as already observed by others. ${ }^{11}$ From the voltammograms it is seen in Figure 3 that for potentials more positive than $0.2 \mathrm{~V}$, the total anodic charge is basically related to the electrooxidation of ethanol on platinum, and therefore, simple inspection of the E/I potentiodynamic profiles reveals that the electrode containing $\mathrm{Pt}$ deposited at $-0.9 \mathrm{~V}$ is more active to oxidize the organic compound than the one containing Pt deposited at $-0.2 \mathrm{~V}$. One should expect to observe the opposite as more charge was used to deposit Pt at this latter potential more Pt should have been deposited and consequently, this electrode should be more active for ethanol electro-oxidation. 


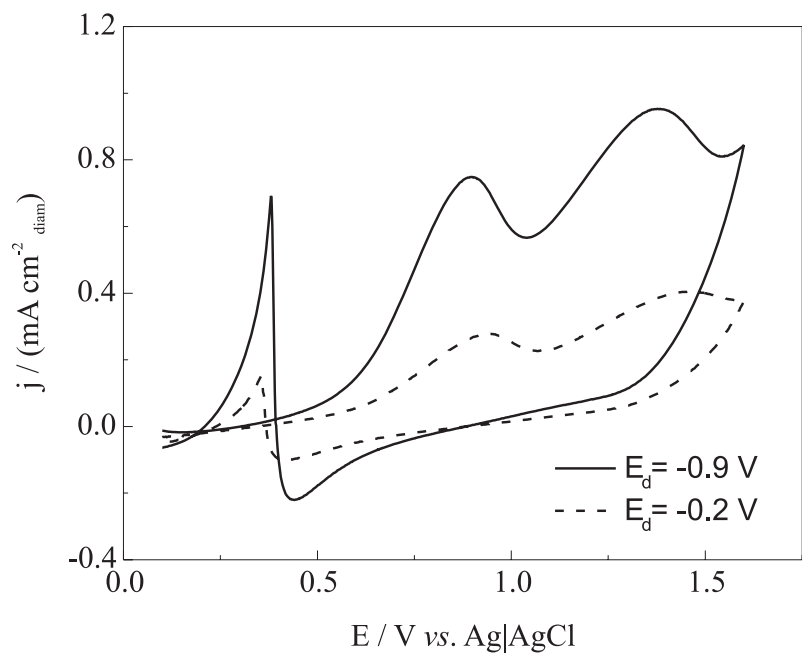

Figure 3. Potentiodynamic E/I profiles for $\mathrm{BDD}(\mathrm{Pt})$ electrodes in $0.5 \mathrm{~mol}$ $\mathrm{L}^{-1} \mathrm{H}_{2} \mathrm{SO}_{4}+0.1 \mathrm{~mol} \mathrm{~L}^{-1}$ ethanol; $\mathrm{v}=50 \mathrm{mV} \mathrm{s}^{-1}$. Pt deposition conditions: (a) $\mathrm{E}_{\mathrm{d}}=-0.9 \mathrm{~V} ; \mathrm{Q}_{\mathrm{d}}=787.6 \mathrm{mC} \mathrm{cm}^{-2}$; (b) $\mathrm{E}_{\mathrm{d}}=-0.2 \mathrm{~V} ; \mathrm{Q}_{\mathrm{d}}=991.2 \mathrm{mC} \mathrm{cm}^{-2}$.

Figures $4 \mathrm{a}$ and $4 \mathrm{~b}$ show the SEM micrographs of the $\mathrm{BDD}(\mathrm{Pt})$ surfaces with $\mathrm{Pt}$ deposited at $-0.2 \mathrm{~V}$ and $-0.9 \mathrm{~V}$, respectively. It can be seen that both samples exhibit uniform surface with faceted grains with Pt particles scattered over the surface (white dots). Qualitatively it is clearly noted that application of a less negative deposition potential $(-0.2 \mathrm{~V})$ resulted in a BDD film containing less Pt particles (Figure 4a), although more charge passed through the deposition bath. A possible explanation for this fact was given by Kuwana and coworkers, ${ }^{17}$ in their voltammetric study of $\mathrm{Pt}$ deposition on graphite from its chloride complex. The authors observed that the $\mathrm{PtCl}_{6}{ }^{2-}$ ion reduction process is a multi-step one, involving adsorption of the complex ion and rupture of the $\mathrm{Pt}-\mathrm{Cl}$ bonds as it is being reduced. However, at lower potentials $\mathrm{Pt}(\mathrm{IV})_{\text {ads }}$ is reduced to $\mathrm{Pt}(\mathrm{II})_{\text {ads }}$ and these adsorbed species may either detach from the surface giving soluble Pt(II) ions or disproportionate resulting in deposited $\mathrm{Pt}^{0}$ and $\mathrm{Pt}(\mathrm{IV})$ soluble ions, according to the non-stoichiometric equations:

$\mathrm{Pt}(\mathrm{IV})_{\text {ads }}+2 \mathrm{e}^{-} \rightarrow \mathrm{Pt}(\mathrm{II})_{\text {ads }}+\mathrm{Pt}(\mathrm{II})_{\text {soln }}$

$\mathrm{Pt}(\mathrm{II})_{\text {ads }} \rightarrow \mathrm{Pt}^{0}+\mathrm{Pt}(\mathrm{IV})_{\text {soln }}$

The proposed mechanism was also admitted by Arvía and coworkers on studying the same process on a HOPG surface using STM. ${ }^{18}$ Hence, according that mechanism, at low deposition potentials only a fraction of the total cathodic charge is effectively used for the production of deposited metallic platinum. The other fraction reduces $\mathrm{PtCl}_{6}{ }^{2-}$ to other soluble complex ions. Therefore, we can conclude that current efficiency of Pt deposition at $-0.9 \mathrm{~V}$ is larger that at $-0.2 \mathrm{~V}$.

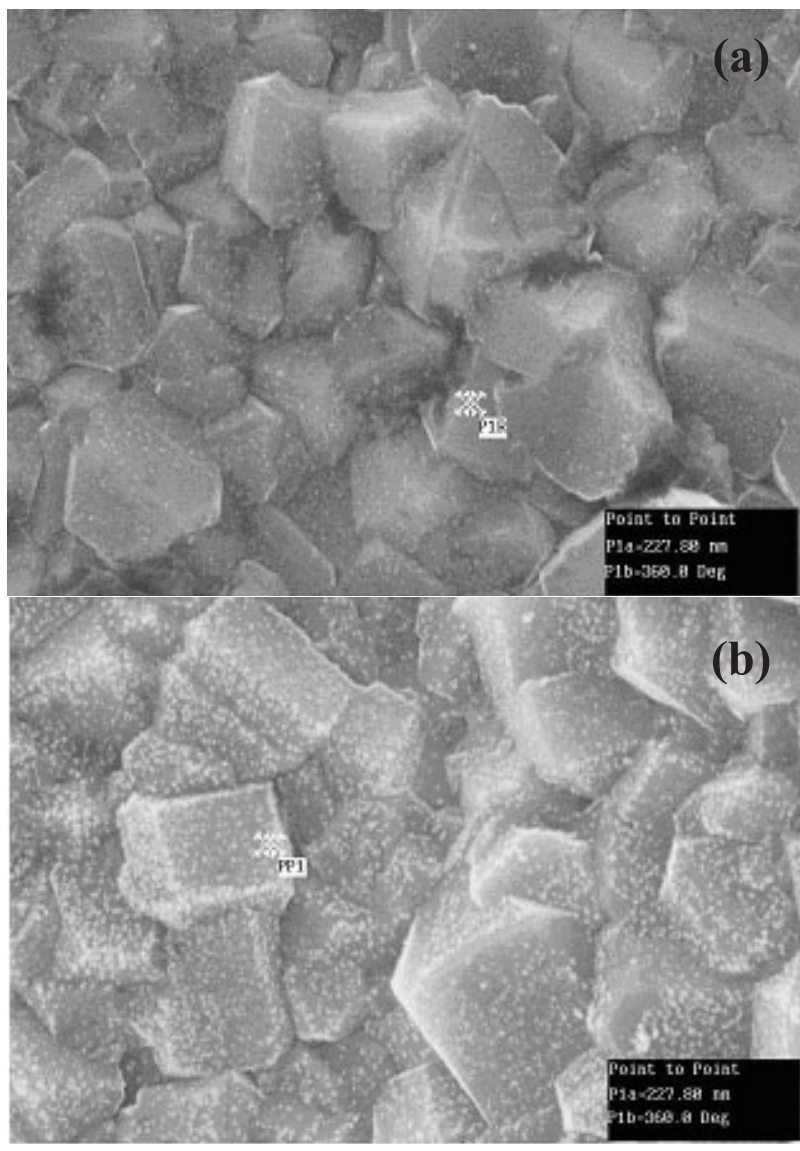

Figure 4. SEM micrographs of BDD films containing Pt particles electrodeposited at two different deposition conditions: (a) $\mathrm{E}_{\mathrm{d}}=-0.9 \mathrm{~V} ; \mathrm{Q}_{\mathrm{d}}=787.6 \mathrm{mC}$ $\mathrm{cm}^{-2}$; (b) $\mathrm{E}_{\mathrm{d}}=-0.2 \mathrm{~V} ; \mathrm{Q}_{\mathrm{d}}=991.2 \mathrm{mC} \mathrm{cm}^{-2}$. Magnification: $1500 \times$.

\section{Effect of the substrate pre-treatment}

To investigate the effect of the anodic pre-treatment of the substrate on the electrodeposition of Pt on BDD films, prior to Pt electrodeposition the $\mathrm{BDD} \mid 0.5 \mathrm{~mol} \mathrm{~L}^{-1} \mathrm{H}_{2} \mathrm{SO}_{4}$ electrode was anodically polarized in the OER potential region. Three freshly prepared BDD film electrodes were submitted each one to the following different pre-treatment procedures: (a) two consecutive triangular potential scans in $0.5 \mathrm{~mol} \mathrm{~L}^{-1} \mathrm{H}_{2} \mathrm{SO}_{4}$ at $50 \mathrm{mV} \mathrm{s}^{-1}$ between 0 and $1.6 \mathrm{~V}$; (b) procedure (a) + anodic polarization in $0.5 \mathrm{~mol} \mathrm{~L}^{-1} \mathrm{H}_{2} \mathrm{SO}_{4}$ at $2.0 \mathrm{~V}$ for $10 \mathrm{~min}$ and (c) procedure (a) + anodic polarization in $0.5 \mathrm{~mol} \mathrm{~L}^{-1} \mathrm{H}_{2} \mathrm{SO}_{4}$ at $2.0 \mathrm{~V}$ for $3 \mathrm{~h}$. Procedure (a) is necessary due to electrode inertness as already pointed out in the former section. Following pre-treatment, each electrode was submitted to a linear potential sweep from $0.3 \mathrm{~V}$ to $-2.0 \mathrm{~V}$ at $50 \mathrm{mV} \mathrm{s}^{-1}$ in the deposition bath for $\mathrm{Pt}$ electrodeposition. Figure 5 shows the three resulting voltammograms. When the electrode was submitted to either pre-treatment (a) or (b), the amount of deposited Pt was apparently the same (Figure 5, (a) and (b)). However, 
Pt deposition overpotential is higher for the anodically treated electrode (Figure 5 (b)), as the cathodic current peak potential, $\mathrm{E}_{\mathrm{P}}$, was around $0.2 \mathrm{~V}$ more negative $\left(\mathrm{E}_{\mathrm{P}} \approx-0.7 \mathrm{~V}\right)$ than the corresponding for the "untreated" electrode $\left(\mathrm{E}_{\mathrm{p}} \approx\right.$ $-0.5 \mathrm{~V})$. Hence, anodic polarization results in a BDD surface less susceptible to Pt deposition. HER is also affected by the electrode pre-treatment made prior Pt deposition as it also shifted to more negative potentials. Conversely, Figure 5 (c) shows that after polarization at $+2.0 \mathrm{~V}$ for $3 \mathrm{~h}$, less $\mathrm{Pt}$ was deposited and the deposition current peak was barely noted; a shoulder is observed at $c a$. $-1.3 \mathrm{~V}$, and HER apparently started at potentials more negative than $-1.5 \mathrm{~V}$. Therefore, anodic polarizations for prolonged periods of time results in a passivated BDD surface for Pt electrode deposition.

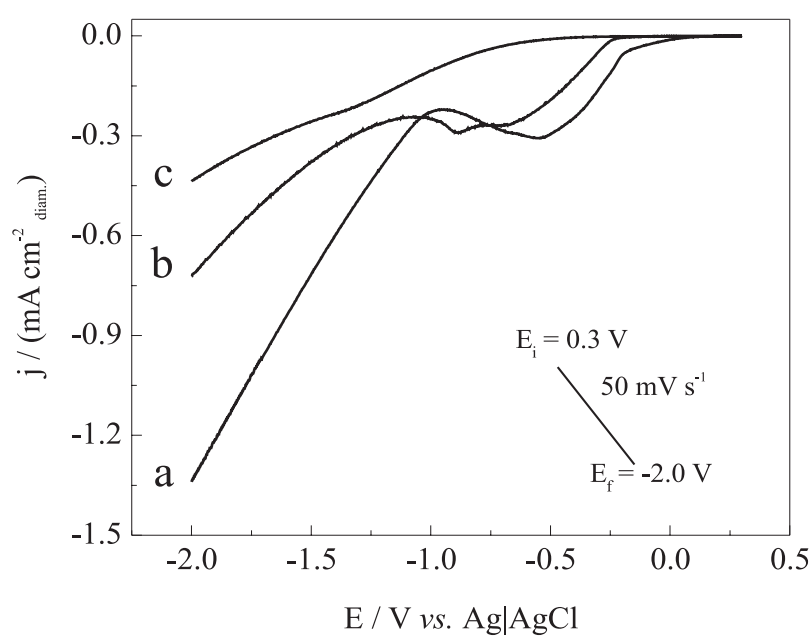

Figure 5. Linear potential sweep voltammograms for different BDD electrodes in $3.8 \times 10^{-3} \mathrm{~mol} \mathrm{~L}^{-1} \mathrm{H}_{2} \mathrm{PtCl}_{6}+0.1 \mathrm{~mol} \mathrm{~L}^{-1} \mathrm{KCl}, \mathrm{pH} 3.4$ after anodic polarization at $2.0 \mathrm{~V}$ in $0.5 \mathrm{~mol} \mathrm{~L}^{-1} \mathrm{H}_{2} \mathrm{SO}_{4}$ for different times: (a) $0 \mathrm{~min}$; (b) $10 \mathrm{~min}$; (c) $3 \mathrm{~h}$.

As we were not able to estimate the ammount of deposited platinum from our experiments we quantified this parameter in terms of the percentage of platinum, $\mathrm{p}_{\mathrm{Pt}}$, on the diamond surface as determined by EDS analysis (spectra not shown). Although EDS is regarded only as a semi-quantitative technique, the data can be used reasonably for comparative studies. Electrochemical areas of the deposits, $\mathrm{S}_{\mathrm{Pt}}$, were estimated from the cathodic charge related to the Pt oxide layer reduction which, accordingly, is equal to $420 \mu \mathrm{C} \mathrm{cm}^{-2} .{ }^{19}$ Normally, the electrochemical area of platinum electrodes is determined by measuring the charge related to the formation of a monolayer of adsorbed hydrogen..$^{19}$ However, when small quantities of Pt were deposited on the BDD electrode, the usual $\mathrm{H}^{+}$ adsorption region on $\mathrm{Pt}$ was not clearly observed (see Figure 2) and therefore, instead of using the usual procedure, the electrochemical area was determined from the oxide reduction charge. Figure 6 shows the influence of anodizing time, $\mathrm{t}_{\mathrm{an}}$, at $+3.0 \mathrm{~V}$ in $0.5 \mathrm{~mol} \mathrm{~L}^{-1} \mathrm{H}_{2} \mathrm{SO}_{4}$ on $\mathrm{p}_{\mathrm{Pt}}$ and on $\mathrm{S}_{\mathrm{Pt}}$. As can be seen, Pt cannot be electrodeposited on freshly prepared BDD electrode $\left(t_{a n}=0 \mathrm{~min}\right)$. However, when the electrode is submitted to an anodic polarization for 10 minutes it is activated for electrochemical processes and $\mathrm{Pt}$ can be deposited. Thus, short anodic polarization time causes the same activating effect as the potentiodynamic activation already described. Similar behavior was observed by Fujishima and coworkers on their studies on the effect of oxidative treatment of BDD surfaces on the chemical deposition of Pt. ${ }^{11}$ It is generally accepted that as-grown BDD surfaces are totally hydrogenated and therefore they are typically nonpolar, and as such they are regarded as hydrophobic because of their weak interaction with water molecules. Conversely, oxidation of a BDD film leads to the formation of surface $\mathrm{C}=\mathrm{O}$ or $\mathrm{C}-\mathrm{O}-\mathrm{C}$ groups resulting in a more hydrophilic surface. ${ }^{20,21}$ Therefore the observed activation of the electrode can be explained in terms of a decrease of hydrophobicity of the surface. Nevertheless, Figure 6 also shows that anodic polarization times longer than 10 minutes, instead of increasing activation of the surface, causes a decrease in the capability of $\mathrm{Pt}$ electrodeposition. Deactivation of the electrode by anodic treatment was also noted by Fujishima and coworkers who observed a decrease in the efficiency of $\mathrm{Cu}$ electrodeposition when a BDD electrode was submitted to an exhaustive anodic pre-treatment. ${ }^{14}$ They attributed the fact to the electrostatic inhibition exerted by the oxygen present on the surface. These groups can form an oxide layer, which can exert an eletrostatic hindrance effect, i.e. by electrostatic repulsion the distance between the metalic ion and the electrode surface increases, causing a decrease on the charge transfer rate. Other possible cause for the observed difficulty of metal electrodeposition on an anodized BDD electrode is the blocking of active sites of the BDD surface by the oxide species. Site blocking effect is also regarded as an explanation for the decrease of surface reactivity of the oxidized film for OER.22

In the inset of Figure 6 it is shown the dependence of the electrochemical area, $\mathrm{S}_{\mathrm{Pt}}$, with $\mathrm{t}_{\mathrm{an}}$. As expected, it shows the same trend observed for the change of $\mathrm{p}_{\mathrm{Pt}}$ with $\mathrm{t}_{\mathrm{an}}$. However, it is noteworthy to observe an interesting behavior. In the experimental conditions an anodizing time of 10 min resulted in an amount of deposited Pt of 4.54\% and when the electrode was anodized for 60 min only $11.9 \%$ of that amount was deposited $\left(\mathrm{p}_{\mathrm{Pt}}=0.53 \%\right)$. However, the reduction in the electrochemical area did not follow that ratio. In fact, when $\mathrm{t}_{\text {an }}=10 \mathrm{~min}, \mathrm{~S}_{\mathrm{Pt}}=25.4$ $\mathrm{cm}^{2}$ and when $\mathrm{t}_{\mathrm{an}}=60 \min , \mathrm{S}_{\mathrm{Pt}}=13.8 \mathrm{~cm}^{2}$ showing a reduction in the electrochemical area of $54.3 \%$. This observation is an evidence of the fact that the degree of 
dispersion of the deposited Pt is inversely proportional of the amount of Pt on the surface. This trend is more clearly noted in the plot of Figure 7.

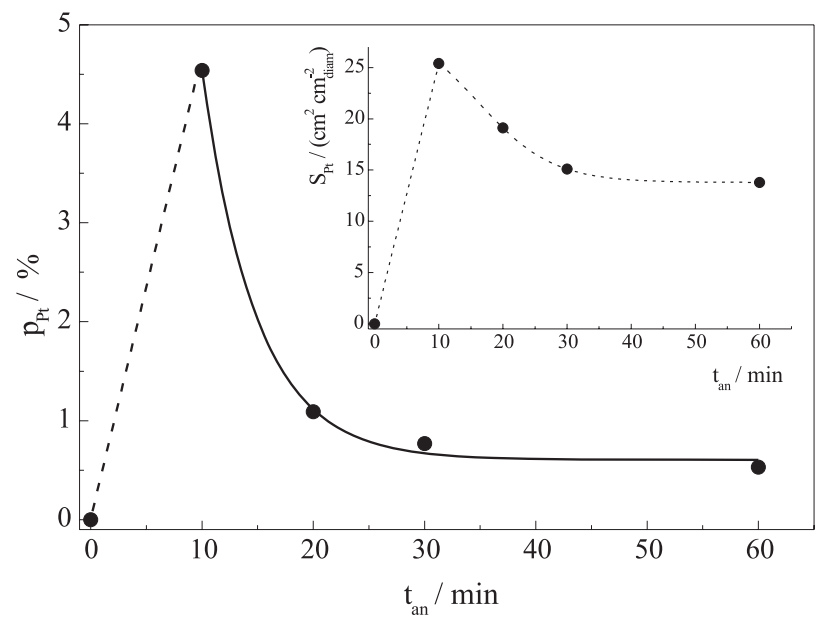

Figure 6. Dependence of Pt percentage in $\mathrm{BDD}(\mathrm{Pt})$ electrodes with anodic pre-polarization time in $0.5 \mathrm{~mol} \mathrm{~L}^{-1} \mathrm{H}_{2} \mathrm{SO}_{4}$. Insert: Dependence of electrochemical area of $\mathrm{BDD}(\mathrm{Pt})$ electrodes with anodic pre-polarization time in $0.5 \mathrm{~mol} \mathrm{~L}^{-1} \mathrm{H}_{2} \mathrm{SO}_{4}$.

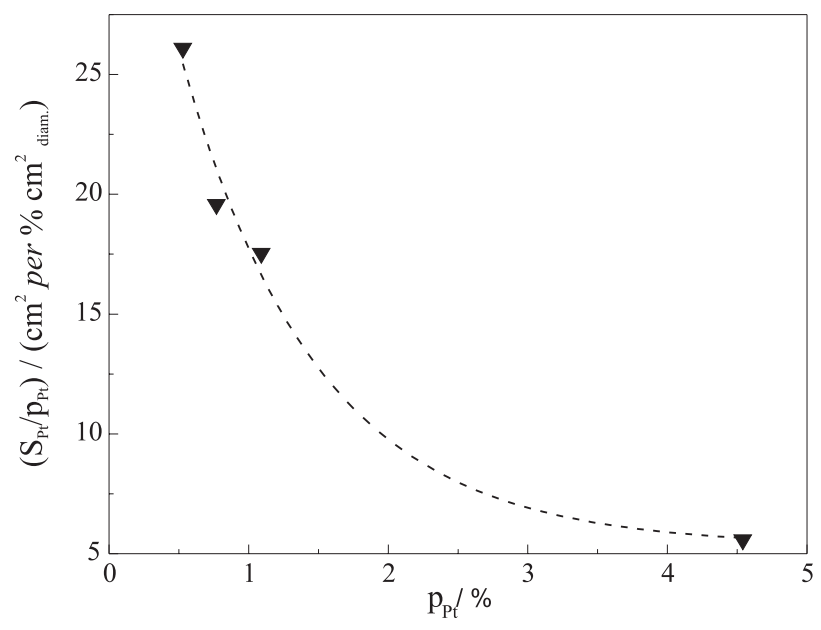

Figure 7. Normalized electrochemical area $\left(\mathrm{S}_{\mathrm{P} t} / \mathrm{p}_{\mathrm{Pt}} \%\right)$ on Pt percentage $\left(\mathrm{p}_{\mathrm{Pt}} \%\right)$.

It shows that the specific electrochemical area, $\mathrm{S}_{\mathrm{Pt}} / \mathrm{p}_{\mathrm{Pt}}$ decreased with increasing platinum loading, as already observed for platinum electrodeposition on glassy carbon and in Nafion ${ }^{\circledR}$ films. ${ }^{23}$ The interaction of metal particles with carbonous surfaces is relatively poor, as observed by other authors who showed that Pt particles present relatively low stability on an as-grown BDD surface. ${ }^{12}$ On the other hand, Pt chemical deposition is more efficient when performed on anodized BDD surfaces. ${ }^{11}$ It was observed that presence of surface oxides on both finely divided carbon ${ }^{4,5}$ and Ge electrodes ${ }^{24}$ results in more dispersed deposited particles. Therefore, the observed increase of the metal dispersion is explained in terms of the presence of electrochemically generated surface oxides which probably inhibit the coalescence of Pt particles.

\section{Conclusions}

Surface properties of BDD films can be electrochemically tailored to control electrodeposition of platinum and deposit characteristics, via controlling the oxidation level of its surface.

Platinum cannot be electrodeposited on a freshly prepared BDD electrode; however, potentiodynamic cycling or anodic potential steps at short times does activate the electrode. Anodic pre-treatment plays a dual role in the behavior of $\mathrm{Pt}$ deposition on BDD surfaces: $\mathrm{Pt}$ deposition is increased at short-term anodic pretreatments, whereas at longer pre-treatment times $\mathrm{Pt}$ deposition was inhibited. These facts are explained in terms of wetability changes and passivation of the surface. Conversely, the oxide layer formed in these treatments increases the dispersion level of the catalyst.

\section{Acknowledgments}

We are grateful to Dr. E.J. Corat SEM and EDS analysis and helpful discussions, and to $\mathrm{CNPq}$, for the financial support.

\section{References}

1. Couper, A. M.; Pletcher, D.; Walsh, F. C.; Chem. Rev. 1990, 90, 837.

2. Bagotzky, V. S.; Skundin, A. M.; Electrochim. Acta 1984, 29 , 757 and 951; Bagotzky, V. S.; Skundin, A. M.; Electrochim. Acta 1985, 30, 485 and 899.

3. Yang, Y. F.; Zhou Y. H.; J. Electroanal. Chem. 1996, 415, 143.

4. Burguete, C. P.; Solano, A. L.; Reinoso, F. R.; Lecea, C. S. M.; J. Catal. 1989, 115, 98.

5. Antonucci, P. L.; Alderucci, V.; Giordano, N.; Cocke, D. L.; Kim, H.; J. Appl. Electrochem. 1994, 24, 58.

6. Perry, M. L.; Fuller, T. F.; J. Electrochem. Soc. 2002, 149, S59.

7. Granger, M.; Xu, J.; Strojek, J.; Swain, G.; Analytica Chim. Acta 1999, 397, 145.

8. Saha, M. S.; Furuta, T.; Nishiki, Y.; Electrochem. Commun. 2004, 6, 201.

9. Panizza, M.; Michaud, P. A.; Cerisola, G.; Comninellis, C.; J. Electroanal. Chem. 2001, 507, 206.

10. Wang, J.; Swain, G. M.; J. Electrochem. Soc. 2003, 150, E24; Electrochem Solid-State Lett. 2002, 5, E4.

11. Honda, K.; Yoshimura, M.; Rao, T.; Tryk, D. A.; Fujishima, A.; Yasui, K.; Sakamoto, K.; Nishio, K.; Masuda, H.; J. Electroanal. Chem. 2001, 514, 35. 
12. Montilla, F.; Morallón, E.; Duo, I.; Comninellis, C.; Vázquez, J. L.; Electrochim. Acta 2003, 48, 3891.

13. Yoshihara, S.; Shinozaki, K.; Shirakashi, T.; Hashimoto, K.; Tryk, D. A.; Fujishima, A.; Electrochim. Acta 1999, 44, 2711.

14. Ohta, N.; Nakabayashi, S.; Fujishima, A.; Chem. Lett. 1999, 1147.

15. Sumodjo, P. T. A.; Rabockai, T.; An. Acad. Bras. Cienc. 1980, 60, 287.

16. Sumodjo, P. T. A.; Silva, E. J.; Rabockai, T.; J. Electroanal. Chem. 1989, 271, 305.

17. Shimazu, K.; Weisshaar, D.; Kuwana, T.; J. Electroanal. Chem. 1987, 223, 223.

18. Zubimendi, J. L.; Vázquez, L.; Ocón, P.; Vara, J. M.; Triaca, W. E.; Salvarezza, R. C.; Arvía, A. J.; J. Phys. Chem. 1993, 97, 5095.

19. Woods, R. In Chemisorption at Electrodes: Hydrogen and Oxygen on Noble Metals and Their Alloys; Bard A. J. ed.; Marcel Dekker: New York, 1976, ch. 9.
20. Notsu, H.; Yagi, I.; Tatsuma, T.; Tryk, D. A.; Fujishima, A.; J. Electroanal. Chem. 2000, 492, 31.

21. Notsu, H.; Yagi, I.; Tatsuma, T.; Tryk, D. A.; Fujishima, A.; Electrochem. Solid-State Lett. 1999, 2, 522.

22. Ribeiro, M. C.; Ribeiro, E. F.; Sumodjo, P. T. A.; Proceedings of the Electrochemical Society (Symposium on Diamond Materials) 2001, 21.

23. Mikhaylova, A. A.; Khazova, O. A.; Bagotzky, V. S.; J. Electroanal. Chem. 2000, 480, 225.

24. Ehlers, C.; König, U.; Staikov, G.; Schultze, J. W.; Electrochim. Acta 2001, 47, 379.

Received: December 12, 2005

Published on the web: May 11, 2006

FAPESP helped in meeting the publication costs of this article. 